\title{
Predictors of Release from Guantánamo Bay and Detainee Recidivism ${ }^{1}$
}

\author{
Susan Fahey
}

\author{
Department of Criminal Justice, The Richard Stockton College of New Jersey, 101 Vera King Farris Dr, \\ Galloway, NJ 08205, USA
}

\begin{abstract}
Exploring Reports of Recidivism by Guantánamo Bay Releasees. The purpose of this research is to examine what is known about recidivism by Guantánamo Bay releasees. Government reports suggest that approximately 27 percent of these releasees have returned to the battlefield while reporting in the open source media identifies the recidivism rate as nearly 9 percent. Deterrence, labeling and defiance theories were applied to explain their recidivism, and The New York Times' Guantánamo Docket document release was used to code the 779 detainees on whether they were released, their nationality, age, time since release, risk level, intelligence value and other relevant domains. The recidivism data were obtained from the New America Foundation. These datasets were used to model the predictors of release from Guantánamo Bay and the predictors of recidivism for those who were released. Risk level, intelligence value, membership in multiple groups, and being of Yemeni nationality all statistically significantly affected the likelihood of release. However, only time since release predicted recidivism. It is likely that the proportion of detainees identified as recidivists will increase over time, as time to offend and be discovered increases, and as higher-risk detainees are released as part of the Obama Administration's attempts to empty the island prison.
\end{abstract}

Keywords: Recidivism, terrorism, Guantánamo Bay.

\section{INTRODUCTION}

The U.S. government began using Guantánamo Bay detention center (GTMO) as a prison facility in the war on terrorism on January 11, 2002. Reports indicate that it was first populated with only 20 prisoners (Hegland 2007), and that the facility held 779 detainees, 600 to 604 of whom have been transferred ("Guantánamo Docket" n.d.; "Guantánamo Files" n.d.; "The Guantánamo Files" (WikiLeaks) n.d.; "Guantánamo Papers" n.d.; House Armed Services Committee 2012). According to reports, 166 prisoners remain at the island prison, nine of whom have died there (House of Representatives 2011; The Takeaway 2013). ${ }^{2}$ In June 2013, the Obama Administration appointed attorney Clifford Sloan to reopen and head

*Address correspondence to this author at the Department of Criminal Justice, The Richard Stockton College of New Jersey, 101 Vera King Farris Dr, Galloway, NJ 08205, USA; Tel: (609) 652-4993; Fax: (609) 626-5559;

E-mail: Susan.Fahey@stockton.edu

\footnotetext{
'I acknowledge the assistance of Erich Wagner, who helped immensely at many stages of this paper's preparation. I also acknowledge the funding of the Richard Stockton College of New Jersey's Research and Professional Development fund. All opinions and errors are mine alone.

${ }^{2}$ There is disagreement in the open source media on how many detainees were ever held at GTMO and how many remain. The Guantánamo Docket asserts 779 total, with 166 remaining (The New York Times). The Guantánamo Papers assert 779 total, with 172 remaining (National Public Radio). The Guantánamo Files (The Guardian) cites 779 total detainees with 178 remaining. This disagreement seems to stem from a lack of information from the U.S. government on this subject. I primarily used the Guantánamo Docket here as they were updated the most recently (July 23,2013 ). The original download of data came from The Guardian at http://www.theguardian.com/ world/datablog/2011/apr/25/Guantánamo-bay-detainees-full-list\#data and it was furnished with information from the files from the Guantánamo Docket. This is explained in more detail in the data section.
}

the Office of Guantánamo Closure in the State Department; the office had been closed since January 2013 (Dougherty 2013).

According to open source reporting from June 2013, there were 86 detainees previously cleared for transfer who were still being held at the prison (Liptak 2013). ${ }^{3}$ Fifty-six of those remaining were from Yemen. The Yemeni group of detainees continues to be held, because their country has been judged too unstable to return them. Other nationalities in continued detention include Afghans, Saudis, Pakistanis, Tunisians, Malaysians, and Chinese, among others, according to the Guantánamo Docket. Many of the remaining detainees have been described as of high intelligence value. For example, Pakistani Ammar al-Baluchi, allegedly a senior member of al Qaida and nephew of Khalid Sheikh Mohammed, has been judged too dangerous to repatriate. Further, 46 of the remaining detainees have been classified as indefinite detainees. This label was assigned in January 2010, as part of the Obama Administration's attempt to close the prison, and the list of those classified as such released as part of a federal lawsuit by a media outlet (Liptak 2013).

\footnotetext{
${ }^{3}$ I use the terms "releasee" or "former detainee" in this paper. However, as the House Armed Services Committee (2012) report noted, there is a difference between released (released with no intention of follow-up) and transferred ("assessed as relatively more dangerous, were conveyed with the expectation that some process would be applied in the receiving nation to mitigate the threat they potentially posed" (House Armed Services Committee 2012:2). As the HASC notes, no single list has been publically released which differentiates between those released and those transferred. It also notes that by mid-2006, releases declined to almost zero while transfers steadily increased starting in mid-2005
} 
Although U.S. government officials often publically painted the detainees as having been captured on the battlefield or performing hostile acts (Taylor 2006), many scholars, lawyers, and members of the U.S. government vehemently disagree about the original guilt of many held at GTMO. ${ }^{4}$ Furthermore, there have been allegations of prisoner mistreatment at GTMO (Savage 2011). Public information regarding the conditions of the detainees' confinement has suffered both from a lack of clarity and much controversy. Yet, given the data, it is not possible to answer questions about either the detainees' original guilt or the conditions of their confinement.

One of the fundamental questions that remain is whether the releasees will reengage in terrorism upon release from GTMO. Thus, my question in this research is: What, if any, factors predict whether a GTMO releasee recidivated? ${ }^{5}$

The organization of this paper is as follows. First, the theories which may explain conformity and recidivism by the GTMO releasees are described. Then, the scant literature on terrorist recidivism at the individual level are reviewed as are the most recent reports from the U.S. government on the detainees at GTMO and the recidivists. Next, I examine the definitions of recidivism and how they have changed over time, the data, methods and hypotheses and the descriptive statistics on the GTMO detainees and recidivists. Two logistic regression models are presented; the first model tests the predictors of

\footnotetext{
${ }^{4}$ Scholars, lawyers, and the U.S. government vehemently disagree about the original guilt of many held at GTMO. Benjamin Wittes, senior fellow in Governance Studies at The Brookings Institution believes it is indiscernible, based on the public record, to determine original guilt or innocence of many currently and formerly incarcerated GTMO detainees (Wittes 2011). On the other hand, Thomas Wilner, counsel of record to GTMO detainees in the Supreme Court's Rasul v. Bush and Boumediene v. Bush rulings, is an outspoken critic of GTMO who hypothesizes that upwards of " $80 \%$ of the individuals incarcerated there over the last nine years were innocent" (Wittes 2011). Wilner, and many subscribing to his views, suggested that like the Germans interned during World War II, GTMO detainees may have been "turned in by personal rivals, picked up by mistake, or sold by bounty hunters to American officials who lacked local knowledge and language skills" (Friedman 2006:2). Some officials acknowledge the idea that not all of those detained at GTMO were factually guilty of any wrongdoing; further, the House Armed Services Committee (2012) acknowledges the long-standing suggestions by many that some of the reengagers may have been factually innocent of any wrongdoing before their detention at GTMO. The original guilt of the detainees is highly controversial. At the request of the Pentagon, the Combating Terrorism Center at the United States Military Academy at West Point determined that data exists to support the conclusions that many individuals were captured "conducting or supporting hostile action against the United States" (Felter and Brachman 2007:3). See also Denbeaux, Denbeax and Gratz (2007).

${ }^{5}$ Beyond the factors I examine in this paper, it is likely that the probability of subsequent terrorist recidivism will also be affected by such things as the individual detainee's experience in prison, the environment and community to which the detainee is released, and the level of radicalization of the releasee although those are not the in the purview of this paper due to a lack of data.
}

detainee release while the second tests the predictors of recidivism. Finally, the results, the limitations of the analysis and the conclusions are discussed. The theoretical framework is explained in the next section.

\section{THEORETICAL FRAMEWORK}

There are three basic criminological theories that try to explain the effects that detention or the enemy combatant label will have on those held at GTMO. ${ }^{6}$ The first is based on the criminological deterrence theory (Beccaria 1764); according to this theory, being imprisoned at GTMO will result in deterring an individual from future hostile acts. Deterrence theory suggests that before deciding whether or not to engage in a terrorist act, the individual will weigh the costs and benefits of such an action. According to deterrence theory, a GTMO releasee should estimate that the legal costs of terrorism are higher upon release and that they may be less likely to engage in terrorism because of this altered view of the costs and benefits of the terrorist action. This is referred to as specific deterrence. Thus, deterrence theory suggests that individuals imprisoned at GTMO and released are less likely to reengage in terrorism so as to avoid further punishment. Alternatively, as Wagner (2012) notes, they may also refrain from reoffending to avoid violating oaths taken upon release that they would not reengage or to avoid violating the Islamic laws of war under the Qur'an. The deterrence theory is a traditional purpose of punishment. It is a societal norm and an expectation that individuals should be less likely to offend postrelease than they were before they were detained.

The second theoretical expectation of post-release behavior by releasees is based on defiance theory (Sherman 1993) and labeling theory (Lemert 1951). According to this branch of theory, being imprisoned at GTMO may result in provoking future law violation because the individual may act defiantly against his prior sanctioners (defiance) or because the individual may have internalized a new "offender" self-image, in this case "terrorist," that can stimulate future offending (labeling). For defiance theory, certain conditions make the defiant reaction more likely. These conditions include that the poorly bonded offender sees the sanction as unfair and stigmatizing and that the

\footnotetext{
${ }^{6}$ Unfortunately, it is not possible to truly test these theories in the strictest sense possible. I am lacking the in-depth, individual-level data to make such a theory test possible. However, these three criminological theories provide a useful heuristic for understanding why a releasee might recidivate or refrain from doing so upon release.
} 
offender denies any shame provoked by the sanction. ${ }^{7}$ Thus, individuals who lack currently active social bonds, such as being married (and implicitly, living with the spouse) and being employed in the legitimate economy, those who do not view being imprisoned as a justly deserved punishment or who feel that it has stigmatized them, or those offenders who feel shame from the imprisonment but do not acknowledge that shame are more likely to reengage in terrorism upon release from GTMO (Sherman 1993). Unlike labeling theory, defiance theory does not require that an individual experience any change in how he views himself.

When defiance theory is applied to the situation of the GTMO releasees, it suggests that an unmarried or unemployed releasee, a releasee who believes the sanction of detention is unfair or that it stigmatizes rather than reintegrates him, or a releasee who denies the shame of his imprisonment is more likely to reengage upon release. It is likely that at least some of the detainees have these qualities although no individual-level data are available to test this perspective. Some of the detainees were (and continue to be) held for more than 10 years. The length of imprisonment, the isolated location of the prison, the foreign location of the prison and the lack of meaningful access to the legal system to gain their release or day in court for most detainees will likely increase the likelihood that many of the detainees will lack active social bonds, that they will view the sanction as unfair and undeserved, and that the detention will produce shame or stigmatize some detainees. This may increase the likelihood of a defiant reaction and as such, defiance is an important theoretical lens through which to view the actions of the releasees and recidivists.

Alternatively, but along a similar vein, Lemert's (1951) labeling theory presents the idea that being detained at GTMO will increase future offending when it involves a change in the offender's self-concept from non-offender to offender. Lemert suggests that primary deviation, in this case, probably the offense(s) which led to the imprisonment in GTMO, may lead to official labeling. It is likely that for the GTMO detainees, being labeled as a terrorist and/or enemy combatant, may be particularly problematic compared to being labeled as

${ }^{7}$ Although I am unable to demonstrate that these conditions are met for the GTMO recidivists given the lack of individual-level data, defiance theory provides an interesting background against which to weigh the recidivism of these offenders. an ordinary criminal offender. Being labeled a terrorist or enemy combatant by the U.S. government is likely to be a difficult label to shed, what is called a "sticky" label.

If this label is internalized, and if it changes the way the releasee views himself, from non-terrorist to terrorist, then it is made more likely that the releasee will reengage in terrorism (Lemert 1951). This may be especially more likely given the high profile status of the GTMO detainees and the length of time many of them have been held. If the releasee has internalized this label of terrorist and begins to think of himself as one, once released, he may seek out associations with others similarly labeled, some of whom may be releasees themselves. If he reengages in terrorism, this will now be termed secondary deviation. Secondary deviation stems from the new label and was caused by the label. The more stigmatized he is by this label, the more deviant his lifestyle, associations, and actions may become.

Lemert (1951) suggests that for some, the labeling can be so strong that the releasee may be unable to return to a normal, law-abiding life if he wants to, because he cannot escape the deviant group and the label itself. It is likely that the label of terrorist and/or enemy combatant for those detained in GTMO is strong enough to stimulate this kind of response for at least some of those detained, similarly strong or stronger than being labeled as a sex offender, even for those who were imprisoned at GTMO erroneously. Lemert suggests that part of the strength of some labels is that those labeled are outcast by regular society and only other outcasts will socialize with them. That is, some releasees will be unable to rejoin regular society when they wish to leave the label behind. They are rejected by conformist society and are only able to associate with other releasees or terrorists. Thus, labeling theory can be interpreted to suggest that detention at GTMO labeled the offender as a terrorist or enemy combatant, and this label may knife off future opportunities to conform, socialize with non-offenders and may narrow his peers to only those who have been labeled as terrorists.

The third theoretical hypothesis is that interaction with the government will be irrelevant; the individual will not offend post-release, because he was never going to commit future offenses (see also Bouffard and Piquero 2010 on this point). This hypothesis most clearly applies to those individuals who were detained at GTMO on little or no evidence of actual guilt of 
terrorism or hostile acts (Friedman 2006). The idea behind this hypothesis is that there are some individuals who were never going to commit any future offenses, regardless of whether they were imprisoned at GTMO. For these individuals, it does not matter whether they were incarcerated, because they will not commit an act of terrorism in the future. However, it is likely impossible to identify from the outset those individuals who will not engage in terrorism in the future. ${ }^{8}$ The very small prior academic literature on the risk of terrorist recidivism is reviewed next.

\section{PRIOR LITERATURE}

Pluchinsky (2008) made some important observations regarding the difficulties inherent in examining recidivism of terrorists. First, he reported that the anecdotal evidence suggests that many, if not most, end up returning to terrorist activity, but there is no comprehensive source for tracking terrorist releasees around the world to monitor their potential reoffenses. In addition, nations vary in whether they treat individuals charged with terrorist-related crimes as common criminals or political prisoners, which likely affects whether and for how long they are imprisoned. This is also likely to influence whether and for what type of rehabilitation or deradicalization program to which they may be subjected. Finally, he reported that prisons may actually be recruiting grounds for extremist activity, increasing the likelihood of recidivism for some of these prisoners upon release.

Dernevik, Beck, Grann, Hogue and McGuire (2009) examined the difficulties of using clinical risk assessments in predicting terrorist recidivism. Prior work by Bonta, Law and Hanson (1998) among others, demonstrated that actuarial risk assessments are far better at differentiating between offenders who will recidivate and those who will not than clinical assessments of risk for common criminals. Yet, clinical risk assessments are exactly what were used as part of the release, transfer or detention decision by the Joint Task Force-Guantánamo (JTF-GTMO). That is, the JTF-GTMO assessment was a clinical risk assessment of the detainee's future risk to U.S. interests by the military officer in charge. This was made on a low, medium or high scale based on the compiled evidence

\footnotetext{
${ }^{8}$ This hypothesis is very similar to the long-running criminological debate about selective incapacitation. Since identifying those who are likely to reoffend at a high rate is very difficult, a selective incapacitation policy risks lengthy prison terms for false positives. That is, the risk is that individuals who are unlikely to reoffend much or at all will be selectively imprisoned for very long periods of time. See also Greenberg (1975).
}

against the detainee, which was primarily composed of his own interrogation statements and that of other detainees about him as well as intelligence gathered by other means ("The Detainees" n.d.). Thus, the JTFGTMO made a clinical risk assessment of the detainees' risk of reoffense in the future when determining whether to release, transfer or continue detention. Ultimately, Dernevik et al. (2009) concluded that any assessments of future risk ought to be based on the ethnic, cultural, social and political context of the detainee. Yet, the majority of prison officials are not qualified to perform such assessments as they are not experts in these domains. Further, it is unknown whether regular violent recidivism risk assessments will accurately predict recidivism for terrorists.

Horgan and Braddock (2010) compiled recidivism rates from a case study of a sample of deradicalization programs for terrorists around the world. ${ }^{9}$ They first noted that there are inherent difficulties in the concept of deradicalization. Their argument centers around the notion that such programs ought to strive for disengagement, which is a role or function change so the individual is no longer participating in violence, rather than deradicalization, which is defined as a lessening of ideological commitment to the cause. They reviewed the literature surrounding programs in Northern Ireland, Colombia, Indonesia, Saudi Arabia and Yemen. The Northern Irish program boasted only 16 individuals rearrested out of 450 in the program. The Colombian program reported no specifics on terrorist recidivism but a 50 percent drop in murder and 75 percent decrease in kidnappings since 2002. Further, the Indonesian program claimed only two or three rearrested individuals out of 458 while the Saudi program claimed only 35 recidivists from about 3000 releasees. The Yemeni program did not report any reoffense rates. The rehabilitative programming that allegedly produced these low recidivism rates varied widely in intensity of the programming, religiosity and in what was expected of those enrolled in them. Overall, if the recidivism rates are to be believed, these programs suggest that terrorism recidivism rates may be quite low upon completion of some types of rehabilitative programming.

To my knowledge, there do not appear to be any other open source, empirical studies of individual

\footnotetext{
${ }^{9}$ Others have examined the array of terrorist deradicalization programs, both from a more theoretical and qualitative case-study approach (Gunaratna 2009) and from a quantitative approach using psychological scales (Kruglanski, Gelfand and Gunaratna 2010). However, they failed to include the recidivism rates for these programs.
} 
terrorist imprisonment and their terrorist related recidivism upon release. The official government reports on GTMO detainees and recidivists are examined in the next section.

\section{Composition of Detainees}

President Obama's Executive Order 13492 requested a full review of all detainees housed at GTMO. This review was issued by the Guantánamo Review Task Force (GRTF) in their final report released in January 2010. According to the GRTF (2010), then-current group of detainees (240) varied in their risk to U.S. interests as well as in the seriousness of the offense for which they had been detained. There were four basic categories of detainee.

The first category was composed of individuals who were detained for having high-level positions in al Qaida (AQ) or other groups accused of terrorist plots or actions against U.S. interests. This included individuals like Khalid Sheikh Mohammed.

The second group was comprised of individuals who had "significant" positions in AQ or other terrorist organizations which had targeted U.S. interests. These individuals were not accused of having operationally participated in terrorist actions and were exemplified by individuals such as Osama bin Laden's bodyguards.

The third category included members of the Taliban and other militia groups known to target Coalition troops. The final group was composed of "low-level foreign fighters" (GRTF 2010:14). These are individuals who were captured in battlefield areas in Afghanistan and likely included very recent recruits with only minimal training and expertise.

There were other detainees who, for undisclosed reasons, were not categorized on these dimensions. It is important to note that this typology only included the 240 then-current detainees and excluded those 530 detainees released by the Bush administration. The GRTF (2010) noted that most of the Bush releasees likely fell into the low-level foreign fighter category due to their perceived lower risk to U.S. interests.

\section{Recidivism Reports}

In April 2009, the Defense Intelligence Agency (DIA) released a report regarding recidivism by the 540 Bush-era releases. They defined confirmed and suspected reengagement as:
Confirmed - A preponderance of evidence-fingerprints, conclusive photographic match, or reliable, verified, or wellcorroborated information-identifies a specific former detainee as directly involved in terrorist activities. For the purposes of this definition, engagement in propaganda does not qualify as terrorist activity.

Suspected - Significant reporting indicates a former detainee is involved in terrorist activities. Analysis indicates the detainee most likely is associated with a specific former detainee or unverified or single-source, but plausible, reporting indicates a specific former detainee is involved in terrorist activities. For the purposes of this definition, engagement in propaganda does not qualify as terrorist activity (DIA 2009:3)

According to DIA (2009), 14 percent of former detainees were either suspected or confirmed reoffenders. Of this 14 percent, 27 individuals were confirmed reoffenders. This included actions such as: becoming a suicide bomber, being arrested and indicted for having a leadership role in a Turkish $A Q$ cell, or arrest and conviction for involvement in a bombing against a gas line. Forty-seven releasees were suspected of reengagement. This included actions such as: being killed in a shootout with Russian authorities and being suspected by Russian authorities of terrorist actions, death in a police raid while planning an attack, or association with Hezb-e-Tahrir, a terrorist group active in Central Asia. Unfortunately, the government reports have failed to identify all of the confirmed or suspected recidivists, leading Denbeaux, Taylor, Camoni, Dabek and Ekiz (2013:644) to claim that the government is either "incapable of accurately identifying recidivists or [is] not interested in being accurate".

However, in 2010, White House Chief of Counterterrorism John Brennan indicated that the reoffending rate of the 540 Bush-era releases was actually 20 percent, rather than the earlier-reported 14 percent (DeYoung 2010). No further details were given regarding the upward revision of the reoffending rate by Bush-era releasees.

In October 2010, the Director of National Intelligence (DNI) released a report including recidivism 
statistics that described all of the 598 then-releasees, including both Bush-era and Obama releasees (DNI 2010). Of the 598, 81 (13.5 percent) were confirmed recidivists, and 69 (11.5 percent) were suspected recidivists. Of the 150 confirmed or suspected recidivists, the $\mathrm{DNI}$ reported that 13 were dead, 54 were in custody and 83 were at large. The DNI added a definition for terrorist or insurgent activities.

For the purposes of this assessment, activities such as the following indicate involvement in terrorist or insurgent activities: planning terrorist operations, conducting a terrorist or insurgent attack against Coalition or host-nation forces or civilians, conducting a suicide bombing, financing terrorist operations, recruiting others for terrorist operations, arranging for movement of individuals involved in terrorist operations, etc. It does not include mere communications with individuals or organization - including other former GTMO detainees - on issues not related to terrorist operations, such as reminiscing over shared experiences at GTMO, communicating with past terrorist associates about non-nefarious activities, writing anti-U.S. books or articles, or making anti-U.S. propaganda statements (DNI 2010:2).

This report also revealed that the DNI utilized a different or modified definition for confirmed or suspected recidivists than the definition reported in a prior Department of Defense (DOD 2008) report outlining definitions of confirmed and suspected recidivism and identified 12 recidivists.

[Confirmed recidivism:] A preponderance of information identifying a specific former GTMO detainee as directly involved in terrorist or insurgent activities. For the purposes of this definition, engagement in anti-U.S. statements or propaganda does not qualify as terrorist or insurgent activity.

[Suspected recidivism:] Plausible but unverified or single-source reporting indicating a specific former GTMO detainee is directly involved in terrorist or insurgent activities. For the purposes of this definition, engagement in anti-U.S. statements or propaganda does not qualify as terrorist or insurgent activity. (DNI 2010:2, emphasis added)

The italicized portions are a particularly interesting addition to the definitions. They indicate that perhaps some of the releasees were engaging in some of this rhetoric, and the Obama Administration's DNI made a determination that much like in the United States, speech does not equal criminal action. Finally, DNI (2010) reported that of the 66 detainees released since the inauguration of President Obama, two (3 percent) were confirmed recidivists and three (4.5 percent) were suspected recidivists. Given they were judged safe to release, it is possible they are of a lower risk profile than those still detained.

In January 2012, the Subcommittee on Oversight and Investigations of the House Armed Services Committee released a review of the GTMO releasees (House Armed Services Committee 2012). That report noted that as of September 2011, the DIA reported that 27 percent of the 599 then-releasees were confirmed or suspected of engaging in insurgent actions.

Finally, the DNI released another report in 2012 , which made it clear that communication between former GTMO detainees did not constitute reengagement. They also released updated confirmed or suspected reengagement estimates. Specifically, they stated:

Former GTMO detainees routinely communicate with each other, families of other former detainees, and previous associates who are members of terrorist organizations. The reasons for communication span from the mundane (reminiscing about shared experiences) to the nefarious (planning terrorist operations). We assess that some GTMO detainees transferred in the future also will communicate with other former GTMO detainees and persons in terrorist organizations. We do not consider mere communication with individuals or organizations - including other former GTMO detainees - an indicator of reengagement. Rather, the motives, intentions, and purposes of each communication are taken into account when assessing whether the individual has reengaged. (DNI 2012:2) 
The inclusion of this paragraph suggests that the Obama Administration wanted to make clear that former detainees who communicated with other former detainees would not be included as recidivists. The DNI appears to have attempted to clarify that associating with other potential criminals is not itself a crime. The DNI also reported that of 599 releasees, 95 (15.9 percent) were confirmed while 72 (12.0 percent) were suspected reengagers (DNI 2012). They also sought to differentiate Bush-era releases from Obama-era releases. The confirmed reengagement rate was cited as 92 of 532 (17.3 percent) releasees for the Bush-era while the Obama-era confirmed rate was three of 67 (4.5 percent). Further, the suspected reengagement rate for Bush-era releasees was 70 of 532 (13.2 percent) while the Obama-era suspected rate was two of 67 (3 percent) (DNI 2012). No further explanations were offered in this short summary report. The definitions for confirmed or suspected remained the same from the prior report.

It is unfortunate the government has not released the names of all of the confirmed and suspected recidivists; the lack of information makes studying the recidivists eminently more difficult. Further, there is likely to be underreporting of the reoffending even in the government's own intelligence, meaning it is likely there are other recidivists whose reoffending has not yet been discovered by the intelligence community. Thus, both the government and open source media estimates of recidivism are both likely undercounts, meaning that essentially, the number of total recidivists is undetermined, and most likely, higher. The data and methods used in this study are examined next.

\section{DATA AND METHODS}

A combination of open source media and official data are used in this research. I started with The Guardian's (UK) rectangular file, which listed name, aliases, and internment number for all detainees ("Guantánamo Bay detainees - the full list" n.d.). The internment number and name or aliases given were used to match the sparse data from The Guardian file to The New York Times' Guantánamo Docket (NYTGD; "The Detainees" n.d.). The NYTGD contained two different kinds of data.

First, the NYTGD contained information collected by The New York Times itself. It contained the name, age, internment number, and whether, to which country and when the detainee was transferred. Occasionally, the NYTGD reported on and included hyperlinked open source media reports on whether the detainee was suspected of recidivism. The following fields were coded from this data: whether the detainee was transferred, to what country the detainee was transferred, and the date of transfer ( $\mathrm{mm} / \mathrm{dd} / \mathrm{yyyy})$ and whether the detainee was reported as a recidivist. Second, the NYTGD contained information from the DOD document release. This information contained various detainee-specific paperwork, the most important of which was the Joint Task ForceGuantánamo (JTF-GTMO) assessment report. This report varied over time, from 2003 to 2008, but it followed a general theme, which included name, aliases, internment number, date of birth, nationality, an executive summary of the defendant's alleged involvement in terrorism, including whether the detainee was alleged to have been involved in any terrorist groups or was a conscript, an assessment of the detainee's future risk to U.S. interests (low, medium, high), and the detainee's intelligence value (low, medium, high). It also included the date of transfer to GTMO custody, the name of the military officer who performed the risk assessment, the detainee's country of citizenship, and the recommendation of the officer for release without conditions, transfer to another country with conditions, transfer with continued detention or retention at GTMO. If the JTF-GTMO assessment was missing on the domains used here, the other documentation released was examined for it. These other documents included the Combatant Status Review Tribunal Summaries and Transcripts and Administrative Review Board Summaries, when available. There are 29 detainees about which little to no documentation were released or exists. A further 19 detainees were missing data on important domains. Thus, my sample of detainees includes 731 out of 779 detainees. See Table 1 for a list of variables, their sources, coding, and descriptive statistics.

I also needed to supplement the NYT recidivism data to get a more complete account of the recidivists by using the only open source information on the identified confirmed and suspected recidivists from the New America Foundation (New America Foundation 2013; Singh 2013). ${ }^{10}$ The NAF scoured the publically

\footnotetext{
${ }^{10}$ Information which has been released in the NAF summaries about the recidivism include statements such as "took control of Taliban operations in southern Afghanistan" (NAF 2013:Mohammed Yusif Yaqub, row 2) amd "[b]ecame a militant commander in southern Waziristan and directed the October 2004 kidnapping of two Chinese engineers in Pakistan" (NAF 2013:Abdullah Mehsud, row 5).
} 
Table 1: Descriptive Statistics for Transfer and Recidivism Samples

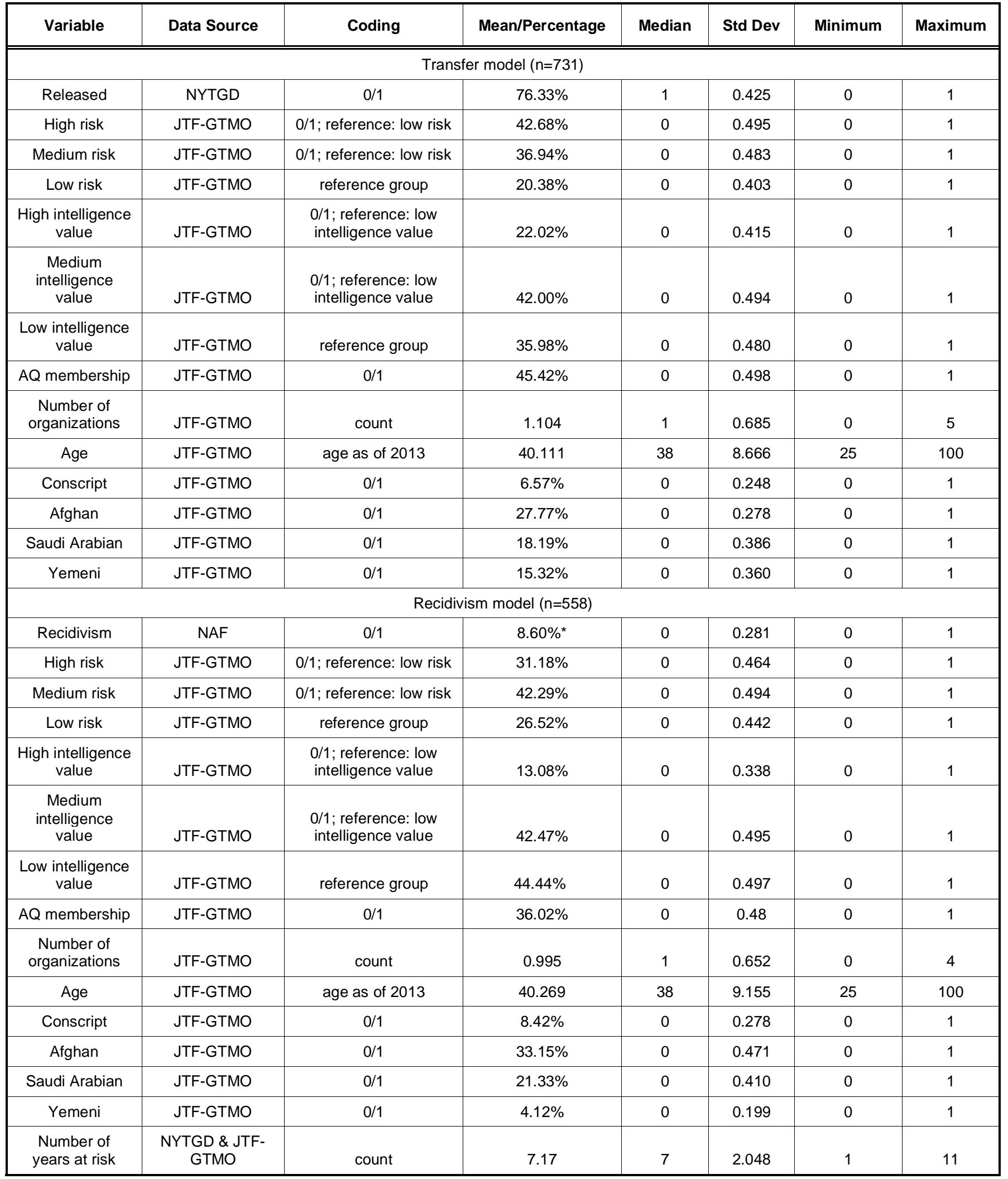

${ }^{*}$ This includes only the 48 recidivists with usable data out of the 558 in the recidivism model.

released DOD and DIA information on the recidivists (name, suspected or confirmed, what the individual was accused of doing and when) and supplemented this with information collected from the open source 
media, including such sources as the NYT, Reuters, NBC News, TIME, Fox News, and the Washington Post, among others. They have been able to find the identity of and recidivism information on 53 recidivists.

\section{Analytical Plan}

First, logistic regression analysis is used on the full sample of 731 detainees with available data to demonstrate which variables influence whether the individual was released from GTMO. Then, a second logistic regression analysis is conducted for 558 of the 600 released detainees with usable data on the important domains; this is to examine the predictors of recidivism. The logistic regression model is appropriate in this case as both of the dependent variables are dichotomous. Both models are run using robust standard errors.

The hypotheses are as follows:

High and medium risk detainees will be less likely to be released than low risk detainees, respectively. Risk should be an important predictor of release according to the JTF-GTMO assessments. When the JTF-GTMO classified the detainee as high risk particularly, statements were included, such as the following: the detainee will "pose a significant threat if released... a HIGH risk, as he is likely to pose a threat to the US, its interests, and allies" ("The Detainees" n.d.:41-majid-mahmud-abdu-ahmad, emphasis in original).

(2) High and medium intelligence value detainees will be less likely to be released than low intelligence value detainees, respectively. High and medium intelligence detainees, as judged by the JTF-GTMO, may be less likely to be released so that interrogators will have more time to exploit their intelligence value. Sentiments like this were expressed in the JTF-GTMO assessment files.

High and medium risk releasees will be more likely to recidivate than low risk releasees, respectively. This hypothesis tests whether the JTF-GTMO is a valuable clinical assessment of risk and predicts recidivism with reasonable accuracy.

(4) High and medium intelligence value releasees will be more likely to recidivate than low intelligence value releasees, respectively. High and medium intelligence value releasees, as judged by JTF-GTMO, should be more connected to terrorist networks and thus, should be more likely to reinvolve themselves in those networks upon release.

(5) Releasees accused of membership in AQ will be more likely to recidivate than those not accused of membership in AQ. This hypothesis tests the notion that $A Q$ membership may be a sticky label so that those who are labeled as $A Q$ may be unable to return to conformity even when they want to. Alternatively, those accused of $A Q$ membership may simply be more committed to terrorism than others and may be more likely to return to the fight.

(6) Releasees accused of membership in more terror organizations will be more likely to recidivate than those accused of membership in fewer or no terror organizations. Those accused of membership in more terror organizations may be labeled more firmly as terrorists or they may be more committed to the cause. In either case, they may be more likely to return to terrorism.

(7) Releasees who have been out of GTMO longer, and thus, at risk longer, will be more likely to recidivate than those who have been out for less time. This hypothesis captures the idea that those who have been out of GTMO longer have had more opportunity to engage in terrorism than those released for a shorter time.

In both models, I control for the age of detainee as older detainees may be more likely to be released and less likely to recidivate. I also control for whether the detainee was a conscript, which may make their release more likely and recidivism less likely. ${ }^{11} \mathrm{I}$ also control for three specific nationalities in both models. First, I control for the Afghans in both the transfer and recidivism models since Afghans returned to Afghanistan would be returning to an active war zone. Because of this, they might be less likely to be released and might be more likely to recidivate. Further, I control for the Saudis, because the Saudis have a famous and controversial terrorist rehabilitation program which may have made release more likely and recidivism less

\footnotetext{
${ }^{11}$ When the U.S. and coalition led war in Afghanistan began in October 2001 and continued to intensify, the Taliban forced older men, young men and even boys into service. Sometimes, if they were able to pay a bribe, they were able to avoid service. Some villages even held a lottery to choose the conscript for the village ("The Detainees" n.d.).
} 
likely. ${ }^{12}$ Finally, I control for the Yemenis. As was noted earlier, Yemen has been deemed too dangerous to allow for repatriation of their detainees. Thus, Yemeni citizenship should affect the likelihood of release and recidivism.

\section{Data Limitations}

An important limitation of the NYTGD data is that it is frozen from the point of the release of the documents, approximately sometime in 2009 or 2010. The latest JTF-GTMO assessment in the NYTGD files is February 21, 2009 ("The Detainees" n.d.:320ablikim-turahun). However, the NYT part of the data was updated as of July 23, 2013. Further, the JTFGTMO detainee assessments are documents which reflect the opinions of the officer authoring it as well as the outcome of potentially many interrogations, with multiple officials from multiple agencies. ${ }^{13}$ The documents are not authoritative documentation of factual or legal guilt or innocence ${ }^{14}$ but rather, are documentation of an official decision-making process. These documents put forth the government's position on the risk, threat, and intelligence value of the detainee and the recommendation for whether to release, transfer or continue detention of the individual.

An important and obvious limitation of the NAF (2013) recidivism data is that it only names 53 releasees as recidivists (4 percent confirmed; 4.7 percent suspected), which stands in stark contrast to the most recent DNI (2012) estimate of 95 (15.9 percent) and 72 (12 percent) confirmed and suspected recidivists. The difference between these estimates is

\footnotetext{
${ }^{12}$ In the JTF-GTMO files of many of the Saudi detainees, it is noted that the visiting Saudi delegation would be willing to consider placing their detainees in that program ("The Detainees" n.d.).

${ }^{13}$ There have been allegations of prisoner mistreatment during interrogations. Further, the U.S. government has admitted to waterboarding three prisoners ("The Detainees" n.d.:10024-khalid-shaikh-mohammed).

${ }^{14}$ Further, Gjelten (2011) highlights the problem with relying on the DOD reports in the NYTGD document release to demonstrate factual or legal guilt. According to Gjelten, the reports themselves often assert connections to terrorism with no equivocation. Yet, when some of these files were assessed by U.S. federal court judges as part of habeas corpus petitions, the evidence was challenged as unreliable or extracted under coercive interrogations. For example, Fouad al-Rabia was held for nearly eight years for alleged membership in al Qaida and a one million dollar donation to the group according to the U.S. government. Judge Kollar-Kotelly reviewed the underlying documents and evidence which led to the determination of alRabia's alleged offenses and ordered him released, stating that "[t]he Government has failed to provide the Court with sufficiently credible and reliable evidence to meet its burden of persuasion. If there exists a basis for at Rabia's indefinite detention, it most certainly has not been presented to this Court" (Gjelten 2011:7). In another case, Judge Thomas Hogan did not release the petitioner, Musab al Mudwani, but stated that "[t]here is no evidence that he fired a weapon in battle or was on the front lines. There is also no evidence that he planned, participated in, or knew of any terrorist plots. ... The Court fails to see how, based on the record, Petitioner poses any greater threat than the dozens of detainees who recently have been transferred or cleared for transfer" (Gjelten 2011:17)
}

that the NAF estimates only include the recidivists identified publically by the government or the media, and the government accounts include recidivists whose identities have not been released. I use the NAF data here as it is the only open source data on the recidivists that includes both public government reports and the open source media. However, if the government's classified data on the unidentified recidivists were made available, it might change the conclusions in important ways.

\section{RESULTS}

\section{Descriptive Statistics}

In Table 1, 76 percent of the detainees with usable data were released. Roughly 43 percent of all detainees with usable data were rated as high risk, nearly 37 percent were rated as medium risk and only 20 percent were rated as low risk, which is the reference group in the analyses. Only 22 percent of the full sample were rated as high intelligence value, while 42 percent were rated as medium intelligence value, with nearly 36 percent rated as low intelligence value, the reference group. Forty-five percent were accused of being members of $A Q$. It is important to note again that the accusations contained in the JTF-GTMO documents are not authoritative determinations of factual or legal guilt or innocence. Thus, the data itself cannot speak to whether the detainees are actually members of $A Q .^{15}$ The number of terror organizations in which the detainee was accused of membership was coded; the mean number of organization was 1.104, with a median of 1 organization and a range of 0 organizations to 5 .

The age of the detainee was coded as of 2013. The mean age in the full sample was approximately 40 years of age, with a median of 38 years old, and a range of 25 to 100 as of 2013. Six and one-half percent of the sample were conscripts, forcibly pressed into service, which included some who claimed to have been kidnapped into service, to have entered into service solely to win the release of a relative who had been kidnapped or conscripted and some who were unable to pay a bribe to avoid the conscription. The conscriptions were with the Taliban for the most part.

\footnotetext{
${ }^{15}$ Further, the $A Q$ membership variable includes membership in $A Q$ proper, $A Q$ cells abroad, such as in London or Italy, an $A Q$ improvised explosive device cell in Pakistan and the $55^{\text {th }}$ Arab Brigade, the unit of $A Q$ that Osama bin Laden charged to fight in Afghanistan. Many of those identified as $55^{\text {th }}$ Arab Brigade members were accused of fighting the U.S. and coalition forces at Tora Bora and aiding in bin Laden's escape from there ("The Detainees" n.d.).
} 
Dichotomous variables for Afghan (27.77 percent), Saudi (18.19 percent) and Yemeni (15.32 percent) nationality were coded and included in the analyses.

The descriptive statistics for the recidivism model were fairly similar although a cursory glance at Table $\mathbf{1}$ shows that recidivism was rare, with only 8.8 percent being either confirmed or suspected of recidivism of those releasees with complete data. Further, the released sample as a group, those at risk of recidivism, appeared to be of somewhat lower risk to U.S. interests according to JTF-GTMO and of lower intelligence value than the full sample. The releasees were less likely to have been accused of $A Q$ membership. The age distribution looks similar. Finally, similar proportions of detainees and releasees were conscripted. The proportion of releasees and detainees who were Afghan and Saudi looked roughly similar, but there was a far smaller percentage of Yemenis released in the recidivism model than their representation in the full sample. Finally, the average years at risk (years since release from GTMO) was 7.17 years with a median of 7 years and a range of 1 to 11 years total. See Table 1 for further descriptive statistics.

\section{Transfer Model}

Although the transfer model is not the main focus of this paper, it is important to first examine what domains predict whether a detainee is released; see Table 2 for full results. Both hypotheses 1 and 2 are partially born out. High risk detainees were statistically significantly less likely to be released than low risk detainees with 97 percent lower odds of release than low risk detainees. Although the coefficient for medium risk detainees was negative, the difference in the likelihood of release between medium and low risk detainees was not statistically significant. High intelligence value detainees were statistically significantly less likely to be released than low intelligence value detainees. The odds of release were 73 percent lower for high intelligence value detainees compared to low intelligence value detainees. There was no statistically significant difference between medium and low intelligence detainees in the likelihood of release.

Further, the more terrorist organizations a detainee was accused of membership in, the less likely he was to be released. For each membership in one more organization, the odds of release decreased by 33 percent. Saudi detainees were about twice as likely to be released, likely owing to its famous deradicalization program. Yemeni detainees were statistically
Table 2: Results of Logistic Regression Analyses for Transfer and Recidivism Models

\begin{tabular}{|c|c|c|}
\hline & Transfer Model & Recidivism Model \\
\hline & $n=731$ & $\mathrm{n}=558$ \\
\hline Variables & $B(\mathrm{se})$ & $B(\mathrm{se})$ \\
\hline \multirow{2}{*}{ High risk } & $-3.547^{* *}$ & -0.065 \\
\hline & (1.325) & $(0.781)$ \\
\hline \multirow{2}{*}{ Medium risk } & -2.279 & -0.279 \\
\hline & $(1.227)$ & $(0.638)$ \\
\hline \multirow{2}{*}{$\begin{array}{l}\text { High intelligence } \\
\text { value }\end{array}$} & $-1.327^{*}$ & 0.598 \\
\hline & $(0.515)$ & $(0.680)$ \\
\hline \multirow{2}{*}{$\begin{array}{l}\text { Medium intelligence } \\
\text { value }\end{array}$} & -0.022 & 0.711 \\
\hline & $(0.436)$ & $(0.462)$ \\
\hline \multirow{2}{*}{ AQ membership } & -0.243 & 0.103 \\
\hline & $(0.322)$ & $(0.417)$ \\
\hline \multirow{2}{*}{$\begin{array}{l}\text { Number of } \\
\text { organizations }\end{array}$} & $-0.387^{*}$ & 0.151 \\
\hline & $(0.186)$ & $(0.331)$ \\
\hline \multirow{2}{*}{ Age } & -0.014 & -0.000 \\
\hline & $(0.015)$ & $(0.018)$ \\
\hline \multirow{2}{*}{ Conscript } & 0.666 & -0.521 \\
\hline & $(0.925)$ & $(0.828)$ \\
\hline \multirow{2}{*}{ Afghan } & -0.047 & 0.183 \\
\hline & $(0.359)$ & $(0.453)$ \\
\hline \multirow{2}{*}{ Saudi Arabian } & $0.726^{*}$ & 0.632 \\
\hline & $(0.366)$ & $(0.399)$ \\
\hline \multirow{2}{*}{ Yemeni } & $-3.256^{\star * *}$ & 0.506 \\
\hline & $(0.398)$ & $(0.819)$ \\
\hline \multirow{2}{*}{$\begin{array}{c}\text { Number of years at } \\
\text { risk }\end{array}$} & & $0.269^{* *}$ \\
\hline & & $(0.101)$ \\
\hline \multirow{2}{*}{ Constant } & $6.230^{* * *}$ & $-4.993^{* *}$ \\
\hline & $(1.337)$ & $(1.286)$ \\
\hline
\end{tabular}

${ }^{* * *}=p<.000 ;{ }^{* *}=p<.01 ;{ }^{*}=p<.05$ (two-tailed).

significantly less likely to be released (94 percent lower odds) than non-Yemeni detainees. No other variables in this model achieved statistical significance, including membership in $A Q$, age, being a conscript or being Afghan.

\section{Recidivism Model}

The results of the recidivism model were quite surprising. Recall that this model includes 558 of the approximately 600 releasees. None of the hypotheses were supported except for hypothesis 7 , which queries whether those at risk longer are more likely to recidivate than those released more recently. This 
hypothesis is supported, suggesting that for every year at risk, the odds of recidivism increased nearly 31 percent. See Table 2 for the results of the recidivism model.

However, no other hypotheses were supported. Neither being high risk nor medium risk both relative to low risk statistically significantly increased the likelihood of recidivism (3). Neither being of high nor medium intelligence value both relative to low intelligence value increased the likelihood of recidivism (4). Further, being accused of AQ membership did not statistically significantly increase the likelihood of recidivism in the model (5). Finally, the number of terror groups in which the releasee was accused of membership did not statistically significantly affect the likelihood of recidivism (6).

The control variables did not have a statistically significant effect on the likelihood of recidivism either. Neither age, conscript status, nor being Afghan, Saudi or Yemeni statistically significantly affected the probability of recidivism in this model. ${ }^{16}$ The results of the analyses are discussed in the next section.

\section{DISCUSSION}

The purpose of this paper was to provide a statistical model of the factors which predicted release from GTMO and a theoretical and statistical framework to differentiate between recidivists and non-recidivists. Since the vast majority of the releasees have not recidivated, it is suggestive that most were deterred from reengaging upon release. That is, most of those who were released were convinced by their detention that either the costs of offending were too high or the benefits of offending were too low or both.

Yet, another explanation of the high degree of conformity in the releasees to date is that some unknown proportion of releasees were never going to recidivate regardless of whether they were detained at GTMO. With or without interaction with the U.S. government, some individuals may never have committed a further offense. It seems likely the conscripts or those who were detained erroneously ${ }^{17}$

\footnotetext{
${ }^{16}$ I suspected that multicollinearity might be affecting the lack of statistically significant results in the recidivism model and as such, examined the correlations for this model, contained in Appendix A. I did not find any correlations greater than $+/-0.6$. Further, extensive model testing and sensitivity analyses did not demonstrate substantive differences in the results upon sequentially excluding variables.

${ }^{17}$ These individuals would more correctly be termed as first-time offenders as they were detained erroneously at GTMO.
}

may be especially likely to fall into this group. It is clear that further study is needed on this question. ${ }^{18}$

In addition, some of the releasees-nearly 9 percent of all releasees according to the NAF (2013) and 27.8 percent according to the DNI (2012) -are reported to have reengaged upon release. Either defiance or labeling theory or both are likely to provide a good explanation of why these offenders have reengaged. For defiance theory, the detainees spent some length of time at GTMO, were cut off from their social bonds, like work and family, were wrested away from their homes and incarcerated in a foreign prison and, in many cases, were denied access to meaningful legal recourse. It is likely that at least some of those detainees will find these sanctions to be unfair and have feelings of shame and stigmatization induced by this incarceration. Shame and stigmatization should increase the probability of a defiant reaction.

Labeling theory (Lemert 1951) posits that those who feel officially labeled as a terrorist or enemy combatant-those who experience a change in selfconcept from non-terrorist to terrorist-are quite likely to reoffend upon release. Most of these releasees were labeled (and in some cases, more than once) as enemy combatants while still in detention and as GTMO releasees when released. These labels are likely to be quite sticky and may make it harder for the releasees to return to a normal life once repatriated. In addition, some of the detainees, such as the Chinese Uighurs, were unable to be repatriated back to their home country and have faced finding a new life in a new country, disconnected from their primary and secondary networks. Finally, some of these detainees may become quite committed to the change in selfconcept to terrorist and may embrace that subculture fully. They may only associate with other terrorists or releasees and reengage. At this point, it is not possible to determine which of these theoretical explanations are best supported. It is likely that both apply.

The recidivism model demonstrated one criminological truism. That is, the longer an offender is followed, the more likely it is he will be found to have reoffended. In fact, the risk of reoffense of common criminal offenses increases steadily upon release, particularly for arrest. In Langan and Levin (2002), nearly a third of criminal offenders were rearrested by the six-month mark, 44 percent by the one-year mark,

\footnotetext{
${ }^{18}$ See note 7 on selective incapacitation
} 
59 percent at two years, and 67 percent at three years. This trend also holds for reconviction and reincarceration with a new sentence although the percentages themselves differ. Over time, many prison releasees will reoffend.

It is likely that the recidivism rate will continue to rise over time and as more of the detainees currently being held for continued detention or prosecution are eventually released. These detainees are generally categorized as higher risk and/or of higher intelligence value, and thus, they may be more connected or committed to terrorism. ${ }^{19}$ In addition, for some detention at GTMO may be viewed as "a badge of honor" (Congressional Record 2011:S2876-S2889; see also Londono 2011). U.S. officials acknowledge that detainees who leave GTMO are like "'rock stars' in the jihadist community" (Herridge and Levine 2010:12). Therefore, it is at least possible this will be a factor in recidivism rates and recruiting the releasees may be viewed positively by terrorist organizations.

A very important limitation of this work is that I do not have access to the government's full list of confirmed and suspected recidivists. ${ }^{20}$ The government has only publically released the identities of 53 recidivists. Further, some of the recidivists had little to no information included in the NYTGD document release so five of the recidivists had to be excluded from the models for missing data. This undoubtedly has influenced my ability to draw strong conclusions and remains a serious limitation of this research.

In addition, this research is limited by the fact that the NYTGD documents are a snapshot in time, with all of the inaccuracies with which official data can be filled. Further, these documents are a product of a social construction of reality and interpretations of interrogations. These interrogations may have used harsh methods and coercion on the detainees. In fact, the U.S. government has admitted to using waterboarding on three detainees during off-site

\footnotetext{
${ }^{19}$ An alternate way of conceptualizing risk in this context would be to devise a measure of the level of commitment to terrorist or insurgent activities or the cause/grievance. Those who demonstrate higher levels of commitment would be expected to be more likely to recidivate than those with lower levels of commitment. Empirically designing such a measure and deploying it to collect individual-level data would likely be a large challenge, but it would be a valuable enterprise.

${ }^{20}$ This is consistent with the findings of the Denbeaux/Seton Hall series on the detainees at GTMO. A prime example of this is the testimony given at the House of Representatives (2011) hearings on Guantánamo Bay Detainee Transfer Policy and Recidivism, which gave a variety of numbers for the same statistic. Denbeaux states, "[DOD fails] to identify names, numbers, dates, times, places, or acts upon which their report relies" (as quoted in Fisher 2011:19).
}

interrogations ("The Detainees" n.d.:10024-khalidshaikh-mohammed). Other allegations of torture during interrogations have been raised. This may place the ethics and the utility of the NYTGD in doubt. They are used here, because it is important to examine what, if anything, predicts whether detainees were released and whether releasees recidivated based on the government's own reporting.

Further, as previously noted, the U.S. government has changed its definition of what constitutes a suspected or confirmed recidivist over time. In addition, there is an overall lack of clarity or consistent definition of what behaviors constitute recidivism, how recidivism ought to be defined, and perhaps most importantly, what behavior each of the reported recidivists engaged in upon release. It is possible that at least some of these difficulties will be corrected in the future if the U.S. government releases a detailed summary of recidivists from GTMO accompanied by their nationality, descriptions of the hostile act, if any, and associated terrorist group. ${ }^{21}$

\section{CONCLUSIONS}

In this paper, the recidivism of the GTMO releasees was oriented within deterrence, labeling, and defiance theories. In addition, what is known about the releasees in the unclassified government reports was examined. Further, I collected data from The New York Times' Guantánamo Docket document release about the detainees on dimensions of risk, intelligence value, terrorist organization membership, and nationality, among other domains. This data was used to populate logistic regression models predicting detainee release and separately, detainee recidivism. It was found that high risk and high intelligence value detainees, and detainees accused of being members of more terrorist organizations, respectively, were all less likely to be released than detainees low on those domains. Further, Saudis were more likely to be released while Yemenis were less likely to be released. In the recidivism model, only one of the hypotheses was supported. Only length of time at risk statistically significantly predicted recidivism for those detainees who had been released from GTMO.

\footnotetext{
${ }^{21}$ More studies of terrorist recidivism at the individual level are sorely needed. Further, access to the U.S. government's recidivism data is needed to gain access to information about the strength of the evidence about the offense of detention, the strength of the evidence regarding the recidivist offense, and the information on the length of detention as well as any coercive measures that were taken against the releasees while they were detained. For an interesting comparison of threat assessments by the DOD and a U.S. federal judge considering a habeas petition for a detainee, see Gjelten (2011).
} 
Ideally, the vast majority of releasees will continue to refrain from recidivism. However, as time goes on, recidivism rates are likely to increase as time at risk increases and the releasees have more time to recidivate. In addition, more time means the government has more time to discover the recidivism. More time also means that higher risk and higher intelligence value detainees may be released eventually, thus potentially increasing the recidivism rate if these detainees are likely to reoffend. Deterrence theory seems to explain why the vast majority of releasees have not reengaged in terrorism although some unknowable proportion may never have recidivated even without the detention at GTMO. This latter case seems a serious possibility for those releasees who were picked up during large-scale sweeps (Friedman 2006; Denbeaux et al. 2007). For those who have recidivated, labeling and defiance theory may be an important explanation of their return to the fight. Overall, it is likely that recidivism estimates will continue to be revised upward as time to reoffend, for that reoffense to be discovered, and the number of detainees released increases.

\section{APPENDIX A: CORRELATIONS MATRIX FOR THE RECIDIVISM SAMPLE}

\begin{tabular}{|c|c|c|c|c|c|c|c|c|c|c|c|c|c|}
\hline $\begin{array}{c}\text { Recidivism } \\
\text { model } \\
(n=558)\end{array}$ & (1) & (2) & (3) & (4) & (5) & (6) & (7) & (8) & (9) & (10) & (11) & (12) & (13) \\
\hline $\begin{array}{c}(1) \\
\text { Recidivism }\end{array}$ & 1 & & & & & & & & & & & & \\
\hline (2) High risk & 0.028 & 1 & & & & & & & & & & & \\
\hline $\begin{array}{l}\text { (3) Medium } \\
\text { risk }\end{array}$ & -0.030 & -0.576 & 1 & & & & & & & & & & \\
\hline $\begin{array}{l}\text { (5) Medium } \\
\text { intelligence } \\
\text { value }\end{array}$ & 0.047 & 0.189 & 0.255 & -0.333 & 1 & & & & & & & & \\
\hline (8) Age & -0.015 & 0.006 & -0.049 & 0.115 & -0.019 & -0.130 & -0.156 & 1 & & & & & \\
\hline (9) Conscript & -0.024 & -0.176 & -0.168 & -0.099 & -0.235 & -0.214 & -0.007 & -0.058 & 1 & & & & \\
\hline (10) Afghan & -0.026 & -0.269 & -0.040 & -0.138 & -0.174 & -0.457 & -0.362 & 0.234 & 0.362 & 1 & & & \\
\hline $\begin{array}{l}\text { (11) Saudi } \\
\text { Arabian }\end{array}$ & 0.074 & 0.169 & 0.068 & 0.006 & 0.217 & 0.493 & 0.219 & -0.200 & -0.158 & -0.367 & 1 & & \\
\hline (12) Yemeni & 0.001 & -0.003 & 0.042 & 0.027 & 0.023 & 0.089 & 0.043 & -0.087 & -0.063 & -0.146 & -0.108 & 1 & \\
\hline $\begin{array}{l}\text { (13) Number } \\
\text { of years at } \\
\text { risk }\end{array}$ & 0.056 & -0.421 & -0.165 & -0.297 & -0.343 & -0.365 & -0.374 & -0.013 & 0.300 & 0.276 & -0.161 & -0.136 & 1 \\
\hline
\end{tabular}

\section{REFERENCES}

Beccaria, Cesare. 1764. On Crimes and Punishment. USA: Seven Treasures Publications.

Bouffard, Leana and Nicole Leeper Piquero. 2010. "Defiance Theory and Life Course Explanations of Persistent Offending." Crime \& Delinquency 56: 227-252. http://dx.doi.org/10.1177/0011128707311642

Bonta, James, Moira Law, and Karl Hanson. 1998. "The Prediction of Criminal and Violent Recidivism among Mentally Disordered Offenders: A Meta-analysis. Psychological Bulletin 123: 123142.

http://dx.doi.org/10.1037/0033-2909.123.2.123
Congressional Record. 2011. "Statements on Introduced Bills and Joint Resolutions." Senate Congressional Record, May 11 S2876-S2889. Retrieved August 14, 2013. (http://beta. congress.gov/congressional-record/2011/05/11/senatesection/article/S2876-1).

Defense Intelligence Agency. 2009. Defense analysis report terrorism: Joint Intelligence Task Force - combating terrorism. Washington, D.C.: U.S. government Printing Office.

Denbeaux, Mark, Joshua Denbeaux, and R. David Gratz. 2007. "The Meaning of "Battlefield" an Analysis of the Government's Representations of "Battlefield Capture and Recidivism" of the Guantánamo Detainees." Seton Hall University School of 
Law Center for Policy \& Research. Retrieved February 1, 2013(http://law.shu.edu/publications/Guantánamo Reports/meaning_of_battlefield_final_121007.pdf).

Denbeaux, Mark, Paul Taylor, Sean Camoni, Edward Dabek and Bahadir Ekiz. 2013. "National Security Deserves Better: "Odd" Recidivism Numbers Undermine the Guantánamo Policy Debate." Seton Hall Law Review 43: 643. Retrieved July 15, 2013 (http://erepository.law.shu.edu/cgi/viewcontent. cgi?article $=1467 \&$ context=shlr\&sei-redir $=1$ \& referer $=$ http $\% 3 \mathrm{~A}$ $\% 2 F \% 2 F s c h o l a r . g o o g l e . c o m \% 2 F s c h o l a r \% 3 F s t a r t \% 3 D 10 \% 2$ $6 q \% 3$ Dterrorist\%2Brecidivism\%26hl\%3Den\%26as_sdt\%3D0 \%2C31\#search=\%22terrorist\%20recidivism\%22).

Department of Defense. (2008, June 13). Return to the fight fact sheet. Retrieved August 1, 2013 (http://www.defense.gov/ news/d20080613Returntothefightfactsheet.pdf).

Dernevik, Mats, Alison Beck, Martin Grann, Todd Hogue and James McGuire. 2009. "The Use of Psychiatric and Psychological Evidence in the Assessment of Terrorist Offenders. The Journal of Forensic Psychiatry \& Pscyhology 20: 508-515. http://dx.doi.org/10.1080/13501760902771217

"The Detainees," New York Times' Guantánamo Docket. Retrieved July 15, 2013 (http://projects.nytimes.com/Guantánamo/ detainees).

DeYoung, Karen. 2010. "Drop Cited in Recidivism among Former Detainees: Guantánamo Review Process better since Bush Era, official says," The Washington Post, February 3, 3.

Director of National Intelligence (DNI). 2010. Summary of the reengagement of detainees formerly held at Guantánamo Bay, Cuba. Washington, D.C.: U.S. government Printing Office.

Director of National Intelligence. 2012. Summary of the reengagement of detainees formerly held at Guantánamo Bay, Cuba. Washington, D.C.: U.S. government Printing Office. Retrieved August 7, 2013 (http://www.dni.gov/files/ documents/ Newsroom/Reports\%20and\%20Pubs/March\% 202012\%20Summary\%20of\%20Reengagement.pdf).

Dougherty, Jill. 2013. "Obama to name D.C. lawyer to lead Guantánamo Bay closure." CNN. Retrieved July 15, 2013 (http://politicalticker.blogs.cnn.com/2013/06/17/obama-toname-d-c-lawyer-to-lead-Guantánamo-bay-closure/).

Felter, Joseph and Jarret Brachman. 2007. "'A Response to the Seton Hall Study: An Assessment of 516 Combatant Status Review Tribunal (CRST) Unclassified Summaries." West Point, NY: The Combating Terrorism Center. Retrieved July 15, $2013 \quad$ (http://www.pegc.us/archive/Organizations/ CTC_resp_to_SH_20070725.pdf).

Friedman, Max Paul. 2006. "A fair, safe way to close Guantánamo." Christian Science Monitor, September 27, pp. 9.

Gjelten, Tom. 2011. "Judges Question Evidence on Guantánamo Detainees." National Public Radio, April 28, Retrieved July 15, 2013 (http://www.npr.org/2011/04/28/135776450/judgesquestion-evidence-on-Guantánamo-detainees).

Greenberg, David. 1975. "The Incapacitative Effect of Imprisonment: Some Estimates." Law and Society Review 9: 541-580. http://dx.doi.org/10.2307/3053339

"Guantánamo Docket." n.d. The New York Times \& National Public Radio. Retrieved July 15, 2013 (http://projects.nytimes.com/ Guantánamo).

"Guantánamo Files." n.d. The Guardian. Retrieved July 15, 2013 (http://www.guardian.co.uk/world/Guantánamo -files).

"Guantánamo Bay detainees - the full list." n.d. The Guardian. Retrieved June 15, 2013 (http://www.theguardian.com/world/ datablog/2011/apr/25/Guantánamo-bay-detainees-full-list).

"The Guantánamo Files." n.d. WikiLeaks. Retrieved July 15, 2013 (http://wikileaks.org/gitmo/).

"Guantánamo Papers." National Public Radio. Retrieved July 15, 2013 (http://www.npr.org/series/135694663/the-Guantánamopapers).
Guantánamo Review Task Force (GRTF). 2010. Final report: Guantánamo Review Task Force. Washington, D.C.: U.S. government Printing Office.

Gunaratna, Rohan. 2006. "The Battlefield of the Mind: Rehabilitating Muslim Terrorists." UNISCI Discussion Papers 21: 148-163. Retrieved July 15, 2013 (http://pendientedemigracion. ucm.es/info/unisci/revistas/UNISCI\%20DP\%2021\%20$\% 20 R O H A N . p d f)$.

Hegland, Corine. 2007. "Guantánamo, the Day After. National Journal, August 4, Retrieved July 15, 2013 (http://www.nationaljournal.com/magazine/Guantánamo-theday-after-20070804?mrefid=site_search).

Herridge, Catherine and Mike Levine. 2010. "Gitmo Repeat Offender Rate Continues to Rise," FoxNews.com, December 8, Retrieved August 1, 2013. (http://www.foxnews.com/politics/ 2010/12/08/gitmo-recidivism-rate-continues-rise/).

Horgan, John and Kurt Braddock. 2010. "Rehabilitating the Terrorists?: Challenges in Assessing the Effectiveness of Deradicalization Programs." Terrorism and Political Violence 22: 267-291. http://dx.doi.org/10.1080/09546551003594748

House Armed Services Committee Print 112-4. 2012. "Leaving Guantánamo: Policies, Pressures, and Detainees Returning to the Fight." Retrieved July 15, 2013 (http://armedservices. house.gov/index.cfm/files/serve?File_id=dd0b4c6e-528e4138-9755-86bae92e1cdb).

House of Representatives. 2011. "House Hearing: Guantánamo Detainee Transfer Policy and Recidivism." House Hearing, 112 Congress. Washington, D.C.: the U.S. government Printing Office. Retrieved July 15, 2013 (http://www.gpo.gov/ fdsys/pkg/CHRG-112hhrg67391/html/CHRG112hhrg67391.htm).

Kruglanski, Arie, Michele Gelfand and Rohan Gunaratna. 2010. "Detainee Deradicalization: A Challenge for Psychological Science." APS Observer 23: 1-3. Retrieved July 15, 2013 (http://www.pvtr.org/pdf/ICPVTRinNews/DetaineeDeradicaliz ation-AChallengeForPsychologicalScience.pdf).

Langin, Patrick and David Levin. 2002. Recidivism of Prisoners Released in 1994. Bureau of Justice Statistics: Special Report. Retrieved August 14, 2013. (http://blueshifthome. com/recidivism/statistics/bjs/BJS\%20-\%20Recidivism\% 20of\%20Prisoners\%20Released\%20in\%201994\%20\%20June\%202002\%20-\%20NCJ\%20193427.pdf).

Lemert, Edwin. 1951. Social Pathology. New York: McGraw Hill.

Liptak, Kevin. 2013. "U.S. Releases Names of 'Indefinite Detainees' at Guantánamo." CNN, June 17, Retrieved July 9, 2013. (http://politicalticker.blogs.cnn.com/2013/06/17/u-s-releasesnames-of-indefinite-detainees-at-Guantánamo/ \& http://i2.cdn.turner.com/cnn/2013/images/06/17/Guantánamo .bay.unclasssified.list.pdf).

Londono, Ernesto. 2011. "For Ex-Detainee, Present Is Far Bleaker Than Past," Washington Post, September 12.

New America Foundation. 2013. Appendix: How Many Guantánamo Detainees "Return to the Battlefield?" Retrieved 7/15/13 (http://newamerica.net/sites/newamerica.net/files/profiles/atta chments/GTMO_Appendix_5-7-2013.pdf).

Pluchinsky, Dennis A. 2008. "Global Jihadist Recidivism: A Red Flag." Studies in Conflict \& Terrorism 31: 182-200. http://dx.doi.org/10.1080/10576100701878457

Savage, Charlie. 2011. "Classified Files Offer New Insights into Detainees." The New York Times, April 24, Retrieved February 1, 2013 (http://www.nytimes.com/2011/04/25/world/ Guantánamo-files-lives-in-an-american-limbo.html? pagewanted=all).

Sherman, Larry. 1993. "Defiance, Deterrence, and Irrelevance: A Theory of the Criminal Sanction." Journal of Research in Crime and Delinquency 30: 445-473. http://dx.doi.org/10.1177/0022427893030004006 
Singh, Ritika. 2013. "New America says Guantánamo Recidivism Rate isn't as High as Intelligence Community Claims." Lawfare. Retrieved August 11, 2013 (http://www.lawfareblog. com/2013/05/new-america-says-Guantánamo-recidivismrate-isnt-as-high-as-intelligence-community-claims/).

Taylor, Jr, Stuart. 2006. "Falsehoods about Guantánamo." The Atlantic. Retrieved February 4, 2013 (http://www.theatlantic. com/magazine/archive/2006/02/falsehoods-aboutGuantánamo /4632/).

The Takeaway. 2013. "Despite Differences, Guantánamo Prison Out of Sight if not Out of Mind in Presidential Election." Retrieved
January 31, $2013 \quad$ (http://www.pri.org/stories/politicssociety/despite-differences-GuantánamoGuantánamo prison-out-of-sight-if-not-mind-in-presidential-election11640.html).

Wagner, Erich. 2012. "Parole for Guantánamo Releasees: Revisiting a Time-tested Concept." Combating Terrorism Exchange 3. Retrieved August 15, 2013 (https://globalecco.org/parole-forGuantánamo-releasees-revisiting-a-time-tested-concept).

Wittes, Benjamin. 2011. "Guantánamo Detainees." Presented at the New America Foundation, January 11, Washington, D.C.

DOI: http://dx.doi.org/10.6000/1929-4409.2013.02.41

(C) 2013 Susan Fahey; Licensee Lifescience Global.

This is an open access article licensed under the terms of the Creative Commons Attribution Non-Commercial License (http://creativecommons.org/licenses/by-nc/3.0/) which permits unrestricted, non-commercial use, distribution and reproduction in any medium, provided the work is properly cited. 